University of Wollongong

Research Online

Faculty of Business - Papers (Archive)

Faculty of Business and Law

$1-1-2017$

Marketing for sustainability: Extending the conceptualisation of the marketing mix to drive value for individuals and society at large

Alan A. Pomering

University of Wollongong, alanp@uow.edu.au

Follow this and additional works at: https://ro.uow.edu.au/buspapers

Part of the Business Commons

Research Online is the open access institutional repository for the University of Wollongong. For further information contact the UOW Library: research-pubs@uow.edu.au 


\title{
Marketing for sustainability: Extending the conceptualisation of the marketing mix to drive value for individuals and society at large
}

\begin{abstract}
The purpose of this paper is to provide new theoretical perspective on marketing for sustainability, particularly for dealing with the environmental threat of climate change. We reconceptualise how marketing is operationalised through the conceptualisation of the marketing mix in order to permit the normalisation of sustainability considerations in business operations and consumption. To the traditional four Ps (product, price, promotion and place) we add but recalibrate for the specific purpose of sustainability participants, processes, and physical evidence, and introduce: promise, principles, and partnership, arguing that each of these may be considered a controllable marketing variable that will contribute to the creation/co-creation of individual and social value. This framework is developed and justified in order to make a novel contribution to marketing theory and practice. Limitations and future research directions conclude the discussion.

\section{Disciplines \\ Business}

\section{Publication Details}

Pomering, A. (2017). Marketing for sustainability: Extending the conceptualisation of the marketing mix to drive value for individuals and society at large. Australasian Marketing Journal, 25 (2), 157-165.
\end{abstract}




\title{
Marketing for Sustainability: Extending the conceptualisation of the marketing mix to drive value for individuals and society at large
}

\author{
Alan Pomering
}

\begin{abstract}
The purpose of this paper is to provide a new theoretical perspective on marketing for sustainability, particularly for dealing with the environmental threat of climate change. We reconceptualise how marketing is operationalised through the conceptualisation of the marketing mix in order to permit the normalisation of sustainability considerations in business operations and consumption. To the traditional four Ps (product, price, promotion and place) we add but recalibrate for the specific purpose of sustainability (participant, processes, and physical evidence), and introduce: promise, principles, and partnership, arguing that each of these may be considered a controllable marketing variable that will contribute to the creation/co-creation of individual and social value. This novel framework is developed and justified in order to make a novel contribution to marketing theory and practice. Limitations and future research directions conclude the discussion.
\end{abstract}

\section{Keywords}

Marketing mix, partnership, principles, priorities, promise, sustainability 


\section{Introduction}

The American Marketing Association's (2013) defining of marketing has repositioned our conceptualisation of marketing, moving it away from the (2004) notion of managing value-based customer relationships that benefit the organization and its stakeholders to managing the "exchange of offerings that have value for customers, clients, partners, and society at large" (AMA, 2013), and departing significantly further from the 1985 definition, which considered only the interests of individuals and organisations, and regarded marketing as: "the process of planning and executing the conception, pricing, promotion, and distribution of ideas, goods, and services to create exchanges that satisfy individual and organizational objectives" (Lusch, 2007). According to Gundlach and Wilkie (2008), the AMA's new aggregate view of marketing ("and its systemic properties", p. 263) recognises a role and responsibility for creating value broadly, "which easily translates into conceptions of markets and people being affected by marketers' actions" (p. 263), and positions its thought and practice for the future, “equipping scholars and practitioners with the capacity to address marketing's everincreasing complexity" (p. 263).

The AMA's conceptualisation of marketing is "considered the standard both for marketing practice and for academic research and education" (Grönroos, 2006, p. 398). While marketing is still about creating value for individual consumers, it now also recognises the importance of partners, and the need for the simultaneous creation of environmental and social value for society at large. The new definition echoes the societal orientation argued for almost half a century earlier by, for example, Kotler and Levy (1969) and Lazer (1969). Marketing's repositioning has called for new approaches to accommodate value creation for society at large, including calls for it to help ameliorate the impacts of climate change. Value for society at large might be equated to the concept of sustainable development, described as "development that meets the needs of the present without compromising the ability of future generations to meet their own needs" (WCED, 1987, p. 43). These needs have recently been articulated through the Sustainable Development Goals (SDGs) (United Nations, 2015).

In celebrating the $75^{\text {th }}$ anniversary of the Journal of Marketing, Kotler (2011) called for not less than the discipline's reinvention, arguing that, to address pressure from 
consumers to change marketing practices, as consumers were no longer choosing brands on functional and emotional grounds only, but also on how companies meet their social responsibilities, "companies must address the issue of sustainability" (p. 132). Similar cries have risen in services marketing (Ostrom et al., 2015), especially as marketing has been under pressure in recent years to prove its contribution to company performance and also develop new capabilities in such diverse fields as new digital communications, the co-creation of value with end-users, and sustainability (Tollin and Schmidt, 2012, p. 509510). Not all have recognised the imperative of marketing's new role, however. Kumar (2015), for example, while highlighting the need for "new thinking in marketing" (p. 6) did not include mention of sustainability in his recent look at what has happened and what to look out for in the discipline, but did lament the decline of conceptual articles and noted calls "from within the community" for more conceptual articles and marketing scholarship (p. 6).

The capacity to address marketing's, and arguably markets', increasing complexity, is recently taken up in this journal by Layton (2016), who argues that reframing marketing as a major discipline within the social sciences will enable its scholars and scholarship to play a stronger role in contributing to debates around solutions for the creation of economic value, and also social value. Layton argues that this value for society at large will permit (enterprise) marketing to move from displaying scant concern for the externalities "which lie at the centre of many of the issues we now face" (p. 3) to address, inter alia, "rethinking sustainability and its impacts" (p. 5). Shultz (2016) echoes Layton's perspective, and notes that casting marketing in this systems-oriented role has typically been captured within the domain of macromarketing, which focuses on: "interactions among markets, marketing and society, ideally toward the enhancement and sustainability of societal well-being and individual quality of life" (p. 257). Layton, however, cautions against the field of marketing fragmenting into "a number of increasingly separate sub-fields, each responding to a narrowly defined range of interests with often very specific methodologies", as this is likely to "restrict our capacity to respond in a holistic manner to the kinds of challenges we now face" (p. 3). The AMA's (2013) re-definition of marketing appears to have averted such an outcome, conceiving all marketing to have as a focus the simultaneous creation of societal value. The approach to marketing for sustainability presented within this article seeks a holistic conceptual approach to how this focus might be included. 
The purpose of this paper, in light of the AMA's broad-based interpretation of contemporary marketing and to advance our understanding of how marketing's externalities might be proactively managed, enhancing both individual and societal wellbeing, is to provide new theoretical perspective on marketing for sustainability. We reconceptualise how marketing is operationalised in order to permit the normalisation of sustainability considerations in business operations and consumption, chiefly through an expanded notion of the marketing mix. We propose a novel framework that, we argue, will better equip scholars and practitioners to work towards greater marketingsustainability outcomes. While we insist that sustainability considerations must permeate each level of a business's strategic planning, from the vision/mission down, we focus our attention on the tactical level of the marketing mix. It is argued that the marketing mix is a logical place to review and mark recommendations in regard to marketing's role for sustainability, given it embraces the controllable variables the firm uses to influence demand by creating value. The AMA defines the marketing mix as the "mix of controllable marketing variables that the firm uses to pursue the desired level of sales in the target market" (AMA, 2016). Increasingly, these sales will accrue to the businesses and organisations that consider the simultaneous achievement of individual and societal value in their market offerings (e.g. Cone Communications, 2015).

The proposed framework expands the set of activities that might be drawn upon within the notion of the marketing mix, taking our point of departure as McCarthy's (1960) four Ps. To these traditional four Ps (product, price, promotion and place), which remain implicit in the AMA's (2007) re-definition of marketing (through the "creating, communicating, delivering and exchanging of offerings") we add from the services marketing literature (Booms and Bitner, 1980; 1981) but recalibrate for the specific purpose of sustainability: participants (or, people); processes; and physical evidence. Further, working inductively from the perspective of emerging sustainability practice, we introduce: priorities, promise, principles, and partnership, arguing that each of these is controllable (that is, manageable) by marketing managers, and will contribute to the creation/co-creation of individual and social value. We note and echo Grönroos's (2006) point that value is not delivered, but is more typically co-created, and add significant nuance to how an enterprise's market offerings come into being. We note that the creation of value for society at large also, indirectly, contributes to the creation of value 
for individuals as consumers increasingly seek pro-social and pro-environmental attributes in their market exchanges (e.g. Cone Communications, 2015).

The conceptual approach proffered in this article is based on inductive research, taking from critical case examples (e.g. Yin, 2014) of contemporary marketing practice, and argues that the proposed marketing-for-sustainability mix of controllable variables is sufficiently robust and expansive to span business sectors (e.g., enterprise, not-for-profit and institutional marketing) and organisational scale, from large, global corporations to SMEs. Indeed, all enterprises and organisations that are in the business of creating value (Porter, 1984) might simultaneously be observed to be in the business of coincidentally creating harm (Polonsky, Carlson and Fry, 2003; Porter and Kramer, 2006). The purpose of the proposed approach is to attend to minimising this harm creation, which is typically borne by society at large, and thereby maximise the creation of individual and societal value. We contend the approach provided here will be sufficiently flexible to have universal applicability, serving the sustainability-oriented needs of those faced with the challenge of managing contemporary marketing (AMA, 2013), in general.

The next two sections will review the literature to describe what marketing for sustainability might look like and the state of play of marketing's confluence with sustainability. A brief summary of marketplace evidence from the demand and supply sides is then presented. This is followed by a description and justification of the proposed marketing for sustainability mix, a discussion, including this paper's limitations and suggestions for future research, and concluding comments.

\section{What Marketing for Sustainability Might Look Like}

The 1987 definition of sustainable development is often the starting point for interpreting what sustainability, and what marketing for sustainability, means in relation to business operations: "development that meets the needs of the present without compromising the ability of future generations to meet their own needs" (WCED, 1987, p. 43). This development is predicated on more responsible production and consumption.

In September, 2015, the General Assembly of the United Nations adopted a set of goals "to end poverty, protect the planet, and ensure prosperity for all as part of a new 
sustainable development agenda", with each goal having specific targets to be achieved by 2030 (United Nations General Assembly, 2015). The 17 Sustainable Development Goals, and their 169 specific targets, focus on "areas of critical importance for humanity and the planet" (UN General Assembly, 2015, p. 1), including: People, Planet, Prosperity, Peace, and Partnership. To help proselytise the SDGs, 9,000 cross-sector companies and 3,000 non-companies across 170 nations have signed up to Global Compact LEAD, with the mission to take a comprehensive approach to sustainability by: (i) operating responsibly in alignment with universal principles; (ii) taking strategic actions that support the society around them; (iii) committing at the highest level; (iv) reporting annually on their efforts; and (v) engaging locally where they have a presence (UN Global Compact, 2016).

Sustainability means the maintenance of both environmental and human health, through the use of renewable rather than finite raw materials and the minimisation and eventual elimination of hazardous effluents and wastes (Charter et al., 2002). Martin and Schouten (2012) define sustainable marketing as "the process of creating, communicating, and delivering value to customers in such a way that both natural and human capital are preserved or enhanced throughout... so that all the marketing processes are environmentally and socially benign while helping to bring about a society in which striving for sustainability is the norm" (p. 238). These authors outline the system conditions for sustainability: the management of each element (i) causes no systematic increases in environmental concentrations of substances from the Earth's crust; (ii) causes no systematic increase in environmental concentrations of synthetic substances; (iii) causes no systematic increases in ecosystem degradation; and (iv) creates no systematic barriers to people meeting their own needs (p. 21). Sustainability marketing "aims at creating customer value, social value and ecological value" (Belz, 2006, p. 139).

\section{Marketing and Sustainability: The State of Play}

There has been a recent and substantial increase in academic focus on sustainability marketing (Belz, 2006, p. 139). For sustainable entrepreneurs (Belz and Binder, 2015), a triple-bottom-line approach is the purpose and focus from the outset. For businesses that must make "drastic changes in their research-and-development, production, financial and marketing practices if sustainability is to be achieved" (Kotler, 2011, p. 132), this 
achievement might come from sustainability-oriented innovation (e.g., Adams, et al., 2016). The novel marketing proposed below provides a blueprint for retrofitting sustainability, by guiding the direction of firms' sustainability-oriented innovation, and is equally relevant for sustainability entrepreneurship start-ups.

Several general texts addressing sustainability from the marketing perspective have recently been published, including those by: Belz and Peattie (2009); Dahlstrom (2011); and Martin and Schouten (2012), while a number of journals, for example, the Journals of Macromarketing; Sustainable Tourism; and Business Ethics focus on the topic. In an effort to identify research priorities that have the potential to advance the service marketing field and deliver value to customers, organisations and society, Ostrom et al. (2015) highlighted improving well-being through transformative service as one of 12 areas for attention, with service sustainability the highest-rated well-being sub-topic. This discussion noted that sustainability should be more holistic than merely dealing with the environment, and include the triple-bottom line (TBL), and service design might consider environmental protection and "how customers and employees can be influenced and/or incentivized to take on roles that reduce a service's negative environmental impact" ( $p$. 141).

While not specifically addressing marketing, Maxwell et al. (2003) recommend that in order to effectively integrate sustainability in product and service development, traditional criteria, such as economic, quality and customer requirements, should be complemented by considerations of environmental and social impacts, and the functionality required (p. 888). At the corporate level, Adams et al. (2016) argue that creating social and environmental value in addition to economic returns via sustainability-oriented innovation (SOI) requires making intentional step-changes to an organisation's philosophy and values, as well as to its products, processes or practices.

While featuring a particular sustainability-oriented brand item in a product mix, such as Toyota's hybrid vehicle options, for a corporation to be perceived as sustainabilityoriented, the entire corporation's operations, including its product range, is required to be underpinned by a sustainability orientation (Tollin et al., 2015). Marketing, after all, might be considered "the whole business seen from the point of view of its final result, 
that is from the customer's point of view. Concern and responsibility for marketing must therefore permeate all areas of the enterprise" (Drucker, 1954, p. 38-39).

This whole-of-enterprise perspective, by necessity, brings marketing for sustainability into the realm of brand positioning, corporate identity and corporate marketing. Marketing 'creates customers' (Drucker, 1954) through positioning, that is, achieving "the way consumers, users, buyers, and others view competitive brands or types of products" (AMA, 2016). Balmer and Greyser (2006) highlight that "a key attribute of corporate-level marketing is its concern with multiple exchange relationships with multiple stakeholder groups and networks" (p. 732), stressing the importance of network partner relationships and recognising that different stakeholders' held images of corporate brands are an amalgam of many often conflicting facets. Balmer's six elements of the corporate marketing mix (2006) detail the antecedents of corporate brand image formation: character, or corporate identity (What we indubitably are); communication (What we say we are); constituencies (Whom we seek to serve); covenant (What is promised and expected); conceptualisations (What we are seen to be); and culture (What we feel we are). Optimal brand image, and positioning, will be achieved when all six Cs align. Managing the elements of the marketing for sustainability mix proposed here will permit firms to more optimally coordinate these six brand- and demand-shaping forces.

Marketing for sustainability considerations must start from the vision/mission and permeate each level of a business's strategic planning. Interface Inc., the carpet tile manufacturer associated with the late Ray Anderson, for example, expresses its mission as the aspiration, "To be the first company that, by its deeds, shows the entire industrial world what sustainability is in all its dimensions: People, process, product, place and profits, by 2020, and in doing so we will become restorative through the power of influence" (Interface Inc., 2017).

The marketing mix level is where strategic marketing planning is put into action. It is the matching of strategy to strategic goals and objectives that accord with the achievement of the organisation's mission. What is conceived in the mix of demand-influencing variables is therefore of critical importance to how marketing managers regard their sphere of influence. Sheth and Parvatiyar (1995), for example, included reorienting the marketing mix in their suggested four corporate strategies for sustainable marketing. In outlining a 
thesis for "sustainability marketing for the poorest of the poor" (p. 171), Kirchgeorg and Winn (2006) propose that sustainability marketing might be achieved within the framework of the traditional four Ps, albeit with "a number of adaptations to the design" of these instruments (p. 180). Martin and Schouten (2012) work within the four Ps framework, cross-referencing these with the system conditions for sustainability (pp. 122-217). Belz and Peattie (2009) consider a sustainability marketing mix of four Cs: customer solutions, communications, customer cost and convenience (p. 149-244), though, referring to the AMA's definition of marketing mix, these elements are perhaps more appropriately seen as the benefit outcomes of marketing's management of a set of controllable variables, and customer cost should perhaps be expanded to also include public good costs.

\section{The Market for Sustainability}

Consumers realise the power they can assert to have an impact in the marketplace, in the products they buy, where they work, and the trade-offs they are willing to make to address social and environmental issues: consumers are "likely to have a positive image (93\%), are more likely to trust (90\%), and are more loyal to (88\%) companies that support social and environmental issues" (Cone Communications, 2015, p. 8). Investorconsumers are also increasingly using sustainability-related data, particularly whether a company's environmental, social, and governance metrics connect with its financial success, as a rationale for investment decisions (Unruh et al., 2016).

Corporate-sustainability reporting has steadily increased among large-cap companies in the U.S. capital markets, as represented in the S\&P 500 Index, up from less than 20 percent in 2011 to 81 percent in 2015 (Governance \& Accountability Institute, 2016), however it appears that the rhetoric is not always matched by reality. While a recent Business for Social Responsibility (BSR)/GlobeScan survey (2016), capturing nearly 300 business leaders from 152 global companies, and representing more than 60 percent of BSR's global membership network, reports that although sustainability is among their CEOs' top five priorities for almost half of the companies surveyed, up from just 35 percent on the previous year, "this greater prioritization and attention has not resulted in greater progress". In Australia, where, overall, 87 per cent of ASX200 companies are now reporting on sustainability to some level, the Australian Council of Superannuation 
Investors argues that a third of these companies "remain less than committed to sustainability reporting, with minimal or basic disclosures that do little to help investors make informed decisions" (Davies, 2015). Also in Australia, following a content analysis of the web pages for leading 30 companies on the Australian stock exchange, Brennan et al. (2011) report "little tangible evidence that sustainable business practices are being implemented" (p. 52).

Marketing, the natural home of creativity and innovation within corporations, is wellplaced to pursue sustainable development's goals of more responsible production and consumption (Jones, et al., 2008). It is evident that more responsible consumption, at the scale needed to mitigate anthropogenic climate change, cannot be achieved by relying solely on consumers' changed buying preferences and behaviours (e.g., Gössling, Hall, Peeters and Scott, 2010); even if supported by public policy interventions, a commensurate move to more responsible business practices and outcomes must also occur.

The business case for sustainability is growing. There is evidence that a greater alignment between business and societal objectives can improve profitability (Porter and Kramer, 2006, 2011; Seebode et al., 2012). A recent study among S\&P 500 companies finds evidence that companies that build sustainability into their core strategies improved profitability (Confino, 2014). Companies actively managing sustainability and planning for climate change were found to achieve an 18 percent higher return on investment than companies that were not, and 67 percent higher than those companies which refused to disclose their carbon emissions, while companies investing to reduce emissions achieved a $50 \%$ lower volatility of earnings over the previous decade and $21 \%$ stronger dividends than their lower-ranking peers (Confino, 2014). BSR (2016) has summarised a range of business benefits from aligning their core business with the SDGs, including: improving business operations and revenue generation (e.g., achieving greater operational efficiency); strengthening the enabling environment (e.g., contributing to stabilising societies and markets); and enhancing reputation and stakeholder relations (e.g., increasing employee engagement and recruitment). Such benefits can be seen in the following examples. WalMart, in collaboration with the Environmental Defense Fund eliminated almost eight million metric tons of greenhouse gas (GHG) emissions from the supply chain by the end of 2013 (Seligmann, 2014), while Duke Energy's use of a 
sustainability filter to revise its method of starting up a natural-gas fired combustion turbine plant, saved fuel use, time and carbon emissions, and resulted in the development of a new start-up calculator that improved efficiency and saved $\$ 2 \mathrm{~m}$. in the first six months at just one turbine station (Hopkins, 2011).

Many of the ramifications of the pursuit of increased sustainability will "go to the heart of the organisation, and will have major implications for the way that business operates," (Charter et al., 2003), but the focus of this article is marketing, and in particular marketing strategy.

\section{Marketing for Sustainability: In the Mix}

Traditional conceptualisations of the marketing mix neither address nor help facilitate marketing for sustainability. As such, Kotler (2011) has called for marketing to be "reinvented" in order to bring about environmental sustainability (p. 132). This sentiment will apply equally for social sustainability, which together with prosperity make up the triple-bottom line. We address such calls, proposing an expansion of the marketing mix, including those variables that the firm might control in the pursuit of the creation of value for customers, clients, partners, and society at large.

In the proposed marketing mix for sustainability (see Figure 1), to the traditional four Ps are added a slightly recalibrated participants (or, people), physical evidence and processes, and, in addition, principles, promise, and partnership. We maintain the convenience of the marketing mix's mnemonic preference for variables, but we also acknowledge observations by Grönroos (2006) that, as originally intended by Borden (1964), a list of mix variables should be context-specific rather than generic, and include, "what should be planned and implemented as marketing as anything that supports value formation" (p. 409). It is not suggested that the elements discussed below might simply be attached to a firm's marketing expression independent of its orientation, but should instead be a reflection and articulation of its authentic sustainability orientation (Tollin et al., 2015). In the remainder of this section we shall expand on the proposed marketing for sustainability mix elements. Underpinning the following discussion is an ecocentric epistemology that recognises an alternative marketing approach based on social, environmental and economic welfare (e.g. Borland and Lindgreen, 2013). 
The four traditional Ps of the marketing mix, product, price, promotion and place, and how they will need to change to facilitate greater sustainability outcomes, is introduced by Kotler (2011, p. 133). This author's comments will therefore form part of the explanation for the first four elements: product, price, promotion and place.

\section{Insert Figure 1 about here}

\subsection{Product}

Product may be defined as, "A bundle of attributes (features, functions, benefits, and uses) capable of exchange or use; usually a mix of tangible and intangible forms" (AMA, 2016), or, "anything that can be offered to a market to satisfy a want or need" (Kotler \& Keller, 2006, p. 372). If product is conceived in terms of value produced by the organisation (Porter, 1984), then the harm that is produced in this process (externalities) should also be considered (Polonsky et al., 2003). Products may be produced using various levels of materials and processes that have differing impacts on the natural environment and human health: life cycle assessment is a quantitative instrument that measures and assesses these relative impacts (Belz and Peattie, 2009). Products might also be considered based on the impacts of their consumption. A Tesla e-vehicle or a bicycle, for example, both involve a similar industrial production process as other forms of conventional transport yet arguably deliver less negative impacts in their consumption and use. 'Green' products should be examined from both perspectives. Further, a departure from personal ownership of products towards their more temporary possession and use, witnessed by the growth of the sharing economy, has the potential to lead to lower production levels, with the impacts reductions this entails, and provides another view of product from a sustainability perspective.

\subsection{Price}

Price, as are all the elements of the marketing mix, is a tool to influence demand and a key positioning driver, influencing how the product, or brand, is perceived by the consumer in relation to competitors (Kotler \& Keller, 2006). Of the various major pricing strategies, cost-based pricing, in which a mark-up is added to the cost of the product, is 
described as the simplest (Kotler and Keller, 2013, p. 364). The real cost of products, however, is seldom captured in pricing decisions. Martin and Schouten note that "a sustainable price accounts fully for the economic, environmental, and social costs of a product's manufacture and marketing while providing value for customers and a fair profit for the business" (p. 171). That is, a product's price should not violate the four system conditions (mentioned above), and should include in cost calculations the cost of the productive process's externalities. Price should not be subsidised by the cost to public goods (e.g., water or air quality, or natural or urban environment amenity), but might be reduced in line with cost reductions due to more efficient resource utilisation.

The experience of some firms' sustainability achievements suggests that as increased sustainability delivers decreased financial and other costs, for example, Interface Inc. (Fishman, 1998), consumers might be able to benefit through lower prices, potentially giving sustainability-oriented products and services a competitive advantage over less responsible brand options.

In the travel sector, the price of air transportation rarely captures the full cost of the product's negative externalities. While some airlines invite passengers to voluntarily offset the carbon produced by their travel by adding a small amount to the price of their ticket, the subscription rates for such offset programmes are typically low (Gössling et al., 2009). Essentially, the cost to the physical environment is not accounted for. Full-cost accounting, which could takes the externalities of air travel into account, is not currently practiced. Booms \& Bitner (1980) note that as pricing decisions for such services, and products, "can only be made with a clear understanding of the value of the service from the customer's point of view" (p. 348), full-cost pricing will need to be accompanied by consumer education. This is one of the roles of the marketing tool of promotion.

\subsection{Promotion}

Promotion is "the means by which firms attempt to inform, persuade, and remind consumers - directly or indirectly - about the products and brands that they sell" (Kotler \& Keller, 2006, p. 536). Marketing communications also represent the brand's voice and allow it to build relationships with customers (Kotler \& Keller, 2006). Belz and Peattie suggest a dual focus for sustainability marketing communications: "to communicate with the consumer about the sustainability solutions the company provides through its 
products, and to communicate with the consumer and other stakeholders about the company as a whole" (2009, p. 180). This will involve joining conversations about firms and their brands within social networks on digital media platforms: an increasingly important forum for marketing-related communications. A third focus, however, is the mode of promotion; while attention is paid to reducing environmental and sociocultural impacts in some areas of the organisation's operations, the means by which this is communicated to key audiences, for example, via lengthy, full-colour brochures, appears devoid of sustainability considerations. Marketing communication's educative role has the capacity to help both business and consumers avoid the tragedy of the commons. Corporate and marketing communications can promote transparency, build relationships, raise the bar on what might be expected as industry standards and minimum expectations, and overcome the obstacles of consumers' perceived quality trade-offs and scepticism when faced with sustainability-oriented marketplace choices (e.g. Matthes and Wonneberger, 2014; Wymer and Polonsky, 2015).

\subsection{Place}

Place, or marketing channels, is the range of "independent organizations involved in the process of making a product or service available for use or consumption" (Kotler \& Keller, 2006, p. 468). These organisations, in producing consumer value, also produce environmental and/or social harm. While some products, for example information-based products might now be distributed digitally rather than physically, such convenience is not available universally. Physical distribution activities remain a necessary marketplace activity, requiring optimal resource planning for inbound, outbound, and reverse logistics (e.g. Quariguasi Frota Neto, et al., 2008).

\subsection{Participants}

Participants was introduced by Booms \& Bitner (1981), along with physical evidence and processes, as part of the services marketing mix, to include the "human actors who play a part in service delivery and thus influence the buyer's perceptions: namely the firm's personnel, the customer, and other customers in the service environment" (Zeithaml, Bitner, \& Gremler, 2006, p. 26). Participants was later referred to as people, however, the original term is preferred here in order to distinguish customers and employees from 
the oft-used People to refer to the broader communities, or society at large, of the triple bottom line.

The inclusion of participants highlights the role of human resource management and the notion of the customer mix as key ingredients in service offerings. Charter et al. (2002) point out that: "an integral part of business sustainability is to remember that "people are the business' and they have to implement change" (p. 29). Therefore, and since "the concept of sustainability and many of the issues that are central to it are not yet widely understood throughout society" (p. 29), these authors note, embracing sustainability will require the introduction, clear communication and careful monitoring of internal marketing programmes to staff, who "should be made aware of the issues through presentations, workshops, internet resources and newsletters, and encouraged to participate in environmental and social programmes" (p. 29). The contemporary view of employees and customers as co-producers of value highlights the need for both to be carefully selected, educated and managed. Marketing traditionally undertakes these customer-management roles through targeting appropriate consumer segments and communicating the organisation's expectations through various marketing communication techniques. But social media platforms and the conversations about brands that they facilitate now bring non-customers, or, more generally, consumers, into the participants category. This recognition necessitates a broader view of the partnerships that sustainability will require, as discussed below.

In tourism, a business activity that relies on environmental quality, participants can be encouraged to co-create value for society at large by reducing their individual environmental footprint. Recent research highlights how hotel guests responded positively to persuasive communication by reducing their resource consumption behaviour (energy and water use), while reporting that their overall satisfaction with their stay was not negatively affected (Warren, et al., 2016). Firms may benefit from open innovation, which can bring about radical innovation for sustainability (e.g., Kennedy et al., 2016).

\subsection{Physical Evidence}


In services, physical evidence consists of "the environment in which the service is delivered and where the firm and customer interact, and any tangible components that facilitate performance or communication of the service" (Zeithaml et al., 2006, p. 27). With regard to physical products, physical evidence might consist of such variables as third-party endorsements and other partner relationships, the provenance of products, such as foods and their ingredients, country of origin, packaging materials, and other brand characteristics that signal the firm's sustainability orientation, such as the use of recycled materials and reverse-logistics collections. Corporate fleets of hybrid or electric vehicles would provide such signalling. Physical evidence has the potential to overlap with other variables in this mix, such as processes and promotion, as it provides consumers the clues they are increasingly seeking to the back-stories behind the array of market offerings they are confronted with. Physical evidence has the potential to provide subtle tie-breaker clues across a wide range of touch-points.

\subsection{Processes}

Processes include the service delivery and operating systems and are the "actual procedures, mechanisms, and flow of activities by which the service is delivered " (Zeithaml et al., 2006, p. 27). Duke Energy, for example, has used of a sustainability filter to revise its method of starting up a natural-gas fired combustion turbine plant, saving fuel use, time and carbon emissions, and resulting in the development of a new start-up calculator that improved efficiency and saved $\$ 2 \mathrm{~m}$ in just six months at one turbine station (Hopkins, 2011). IKEA's early 2014 purchase of the Hoopestown wind farm, able to generate nearly 1.5 times the energy needed to operate all of the store's U.S. operations, will reduce its carbon footprint as it does business (Meany, 2014). Facebook, Google, and WalMart are also investing heavily in renewable energy (Meany, 2014). Processes also include how a firm goes about its learning and knowledge management efforts (Gavronski, et al., 2012).

\subsection{Principles}

Principles are the firm's values and these will form a critical element of its identity and consumers' and other stakeholders' brand image of the firm as sustainability-oriented. Such an image might serve as a tie-breaker in the liking and preference over its rivals for 
the brand perceived as sustainable (e.g., Cone Communications, 2015). Within the vision of Interface Inc., for example, is the principle to: "To be the first company that, by its deeds, shows the entire industrial world what sustainability is in all its dimensions: People, process, product, place and profits - by 2020 — and in doing so we will become restorative through the power of influence." (Interface Inc., 2017). It is evident that such principles might provide the foundation for the brand's promise(s). Principles should be reflected in the firm's public commitment to one or more of the SDGs, which will be 'on display' both in the organisation's mission statement and corporate communications, including its corporate website and reporting, and often in marketing communications, such as its advertising and public relations. Principles might be expected to start with efforts to ameliorate the externalities resulting from the firm's operations, and afterwards, in line with the notion of creating shared value (Porter and Kramer, 2011), expand to enhance the social and economic conditions of the communities in which the firm operates, or society at large. Principles form a natural connection with the firm's promise, described next.

\subsection{Promise}

Promise is captured in Balmer's (2006) notion of covenant (that is, what is promised and expected). Promises are the essence of firms' brands. Promise management, the foundation stone of maintaining relationships with key stakeholders, such as consumers, is discussed by Grönroos (2006, pp. 405-7). Promises around sustainability might be expressed in terms of, for example, the triple bottom line, SDGs, or the system conditions outlined by Martin and Schouten (2012). Promise should be contained in the organisation's mission, the statement of an organisation's raison d'être, situating the purpose and direction of the organisation in the minds of employees, customers, and other stakeholders. Such promises provide firms with benchmarks against which to measure current performance and also yardsticks to assist with future planning. For example, Interface Inc.'s mission includes, inter alia, “We will honor the places where we do business by endeavoring to become the first name in industrial ecology, a corporation that cherishes nature and restores the environment. Interface will lead by example and validate by results, including profits, leaving the world a better place than when we began, and we will be restorative through the power of our influence in the world." (Interface, 2017). Interface makes a clear commitment to sustainability through 
its "Achieving Mission Zero ${ }^{\text {TM" }}$ addendum to its mission: "Interface's dedication to sustainability has evolved into the company's Mission Zero ${ }^{\mathrm{TM}}$ commitment — our promise to eliminate any negative impact Interface has on the environment by 2020 ." (Interface, 2017). Such promises may also be evident in brands' corporate-image advertising and other marketing and corporate communications.

\subsection{Partnership}

Having sustainability-oriented principles, priorities and promises should inevitably make it easier to form effective partnerships with internal and external audiences in order to develop and deliver sustainability performance. Partnership is essential to achieving a whole-systems approach to dealing with unwanted ecological and sociocultural externalities. Partnership can be used to ensure that sustainability reverberates along the entire value delivery network (Gallear, et al., 2012). Partnership will, naturally, occur internally and externally. Internal partnerships to drive sustainability will rely on internal marketing and human resource management, and might include employee suggestion systems that are recognised and rewarded. External partnerships will include the traditional members of a firm's value-delivery network, that is, suppliers, channels, and customers, but might also include those with expertise who might assist the firm achieve its sustainability goals. Relationship management will be a key aspect of this variable (Grönroos, 2006). Mendleson and Polonsky (1995) expand on using strategic alliances to develop credible green marketing, while Hall (1999), referring to the context of tourism, notes that "issues of coordination, collaboration and partnership are now at the forefront of much tourism research on finding new solutions to resource management and destination development problems" (p. 274). The importance of partnerships inside and outside a firm has been noted as critical to the development and delivery of value, highlighting the importance of partner relationship management, the value delivery network, and internal marketing (e.g., Kotler and Keller, 2013), but social-media-driven conversations about corporate brands and their products now requires efforts to effectively collaborate with audiences with whom the firm may have no other relationship with, but who may be representing the interests of society at large.

Considering the implications of Marketing and Sustainability for the future, Charter et al. (2002) observed: "Companies developing strategies of co-operation and collaboration 
will be those that are more likely to be successful - as sustainable solutions will require new forms of partnership. Partnerships may need to be formed with rivals to solve mutual environmental and social problems, with suppliers to reduce impacts, with customers to develop new ways to meet needs or to recycle materials, or with former critics to develop innovative solutions to long-standing problems." (p. 31). When it comes to the complex challenges businesses will face in the pursuit of sustainability, partnership will be central to the concept of co-creation of environmental and social value.

\section{Discussion}

The proposed novel and expanded mix for sustainability marketing argues that stepping beyond the constraints of the traditional four Ps is a necessary condition for contemporary marketers to optimally drive sustainability marketing and facilitate more sustainable consumption that is a marketplace norm rather than a niche. The concept of the marketing was not intended to be constrained by only four elements, but might include any number of variables the firm might manage in order to create value for individuals and society at large. The complexity of the environmental and social challenges facing business in today's critical climate (e.g. Cone Communications, 2015) requires businesses to develop solutions to problems that fall beyond the walls of business as usual. Few businesses can achieve this alone, without considerable additional cost and delay, hence partnership becomes increasingly critical. The same basic argument is made for all the proposed mix elements, above.

Epstein and Roy (2001) observe that pursuing a sustainability strategy is a complex undertaking, especially for global firms. Moving from formulating sustainability-related corporate values, commitment and goals to enacting strategy in the form of market offerings, via the marketing mix, can only considered as complex, yet, equally, necessarily so. Nonetheless, as each of the proposed marketing for sustainability mix elements must be managed and is expected to impact value creation, the contribution of each needs to accounted for.

Székely and Knirsch (2005) argue that in order to measure the extent to which a firm's performance improves as a result of implementing sustainability initiatives the initiatives need to be directly linked to business strategy, and, based on an analysis of corporate 
website reporting, examine the metrics used by 20 major German firms. These authors summarise their findings in terms of economic, environmental, and social metrics, (p. 644), however, while they note an absence of comparability between the 20 firms' reporting they confine their analysis to internal achievements. How the sustainability initiatives might have contributed to value creation for societal at large is not discussed. As the value that is created for individual customers and society at large is to be measured to determine the contribution of each variable in the marketing mix, so too should each variable's simultaneous contribution to the broader societal value be measured. This point is made by Epstein and Roy (2001, p. 599). The contribution of all the proposed mix variables may be measured in terms of sales or profits or in terms of any other organisational goals (AMA, 2016). Just as metrics for the traditional four Ps might be developed (Brooks and Simkin, 2012), so might metrics for these additional variables. Importantly though, organisational goals should include societal as well as corporate aspirations. Frameworks such as triple bottom line reporting, the Global Reporting Initiative and the United Nations Global Compact can assist this task. The framework proposed here should assist the marketer address the reporting requirements of these reporting instruments, as it includes a comprehensive picture of the levers that might be activated within the organisation's market-facing operations, and can help to address the 17 SDGs.

The paper sets out to develop marketing theory (Kumar, 2015; MacInnis, 2011) by extending the marketing mix framework with novel considerations to deal with the complex challenges of sustainability and sustainable development, and to add managerial relevance (Jaworski, 2011) to marketing for sustainability thinking. The extended marketing mix outlined here has been developed inductively, based on examples of firms that addressing the sustainability challenge. Testing the contribution of the proposed elements, both directly and via their interactions, should prove a useful and stimulating direction for future research, particularly as it would provide a means of understanding inter-construct relationships. There is extant a considerable body of different literatures that examine aspects of sustainability marketing, for example, consumer response to sustainability-related marketing communications (e.g., Luchs et al., 2010; Minton et al., 2012), however, claims around market offerings that are more systematically embedded within a sustainability-oriented approach, similar to that achieved by Interface Inc. under the stewardship of the late Ray Anderson, may reveal novel and encouraging insights. Of 
particular interest may be the various interactions between the various marketing variables proposed here. Crowd-sourcing of sustainability initiatives and the co-creation of individual and societal value among employees, consumers and other potential stakeholders also proffers useful future research avenues. The possibility that additional or alternative, controllable marketing variables might also be included in the marketing for sustainability mix is another potentially valuable future research focus. Finally, the impacts of different mixes of the proposed marketing variables on value (co-)creation for different constituents: consumers, clients, partners, and especially society at large, offers exciting marketing management and research opportunities.

\section{Conclusion}

The proposed expanded conception of the mix for sustainability marketing does not seek to replace the considerable volume of extant literature brought forward to assist marketing managers navigate the difficult waters of moving companies and brands towards more sustainable market offerings and the societal impacts of consumption of those offerings. The key purpose of the proposed mix is to remove any obstacles that might result from managers struggling to achieve sustainability within what might be perceived as a discipline-imposed toolbox of just four instruments. The elements proposed here assist by providing more decision areas that will serve as brand-consumer touch-points, and permit broader and deeper conversations with consumers and other stakeholders to assure of sustainability efforts.

As a marketing orientation leads to innovation, thinking more broadly about what is needed in a contemporary orientation for business and having a marketing and societal value orientation might be expected to lead to sustainability-orientated innovation. Orientation signifies "a pattern in company innovation and communication behaviour" (Tollin, et al., 2015, p. 480). These authors highlight that "the kind of innovation most corporate sustainability initiatives result in or give rise to presupposes a radical change in managers' ideas, values and knowledge about the role, purpose and operation of companies" (p. 475). Our better understanding of sustainable consumption (e.g. Prothero, et al., 2011) is useful, but in order to encourage such consumption patterns to become mainstream, a move to greater sustainability marketing by, for instance, embracing decision-making around the expanded mix above can help achieve this outcome. What is 
currently thought of as green marketing (e.g. Kumar, 2016) can, echoing Layton (2016), be viewed simply as marketing.

The proposed mix can provide the marketer with a systematic guide for marketing for sustainability, raising the overall level of sustainability-oriented business in the marketplace, and moving sustainability towards the mainstream rather than having it remain domain of niche segmentation, targeting and positioning, but alone, like green marketing (Wymer and Polonsky, 2015) it cannot offer a panacea for sustainability's system conditions and ethical consumption. Sheth and Parvatiyar (1995) note the role for regulators to complement corporate strategies for sustainable marketing, and this is increasingly evident on both the supply- and demand-sides. Some obvious examples in a number of jurisdictions are, in packaging and labelling (foods), restriction of promotion (tobacco, and other 'sin' products), and restricting consumer age (e.g. purchase of alcohol and tobacco).

The AMA's definition of marketing provides a beacon to guide the efforts of marketing managers to attain their goals. This definition has recently changed, repositioning marketing's role by recognising a broad social responsibility, creating value for society at large concurrent with addressing the needs of and creating value for individual customers. It is proposed that the expanded notion of the marketing mix, above, will better equip marketers to do this. The proposed approach to marketing for sustainability hopefully overcomes marketing's "inability to cope with fundamental shifts in the environment" (Grönroos, 2006, p. 412), and proffers an intellectually demanding, more relevant, and even stimulating exercise for marketing managers. Free of the shackles imposed by old-economy frameworks such as the marketing mix consisting of the traditional four Ps, the expanded marketing mix for sustainability proposed here encourages marketing managers of large and smaller organisations alike to review and recast their marketing management. Having the 10 controllable marketing variables proposed here arguably provides greater clarity and flexibility in the pursuit of increased sustainability outcomes. Treated separately, each of the 10 variables should add capacity to the marketer's management and contribute to increased competitiveness and profits. From an inductive perspective, taken together, the proposed marketing mix provides a theoretical rationale that goes beyond competitiveness and profitability and will result in increased sustainability, or value for society at large. 


\section{References}

Adams, R. Jeanrenaud, S. Bessant, J. Denyer, D. Overy, P., 2016. Sustainability-oriented innovation: A systematic review. International Journal of Management Reviews, 18, 180-205.

American Marketing Association. 2013, 2016, What are the definitions of marketing and marketing research. http://www.marketingpower.com/ content4620.php.

American Marketing Association, 2016. Dictionary, available at: https://www.ama.org/ resources/pages/dictionary.aspx?dLetter=P\#product+positioning. Accessed 17 December, 2016.

Belz, F-M., 2006. Marketing in the $21^{\text {st }}$ century. Business Strategy and the Environment, 15, 139-144.

Belz, F-M \& Peattie, K., 2009. Sustainability Marketing. A Global Perspective: West Sussex: John Wiley \& Sons.

Booms, B.H., Bitner, M.J., 1980. New management tools for the successful tourism manager. Annals of Tourism Research, 7 (3), 337-352.

Booms, B.H. \& Bitner, M.J., 1981. Marketing strategies and organization structures for service firms, in Donnelly, J.H., George, W.R. (Eds), Marketing of Services, Conference Proceedings: American Marketing Association, Chicago, IL: 47-51.

Borden, N.H., 1964. The Concept of the Marketing Mix, Journal of Advertising Research, 1964, pp 2-7 and reprinted in: Baker, M.J. (Ed), Marketing: Critical Perspectives on Business and Management, Vol. 5, Routledge, 2001, 3-4.

Borland, H. Lindgreen, A., 2013. Sustainability, epistemology, ecocentric business, and marketing strategy: Ideology, reality, and vision. Journal of Business Ethics, 117, 173-187.

Brennan, L., Binney, W., McCrohan, J., Lancaster, N., 2011. Implementation of environmental sustainability in business: Suggestions for improvement, Australasian Marketing Journal, 19 (1), 52-57.

Brooks, N. Simkin, L., 2012. Judging marketing mix effectiveness. Marketing Intelligence and Planning, 20 (5), 494-514.

Business for Social Responsibility, 2016. A first look at how companies are responding to the SDGs, https://www.bsr.org/en/our-insights/blog-view/a-first-look-at-how-companiesare-responding-to-the-sdgs. Accessed 2 December, 2016. 
Charter, M., Peattie, K., Ottman, J., Polonsky, M.J., 2002. Marketing and Sustainability, Centre for Business Relationships, Accountability, Sustainability and Society (BRASS), in association with The Centre for Sustainable Design, http://www.research.ucreative.ac.uk/693/1/smart-know-net.pdf. Accessed 4 April, 2017.

Cone Communications, 2015. 2015 Cone Communications/Ebiquity Global CSR Study, http://www.conecomm.com. Accessed 20 July 2016.

Confino, J., 2014. Sustainable corporations perform better financially, report finds, Guardian Sustainable Business, https://www.theguardian.com/sustainablebusiness/2014/sep/23/business-companies-profit-cdp-report-climate-changesustainability. Accessed 14 April, 2017.

Coulter, C., 2013, "Survey reveals sustainability is stalled at most companies", GreenBiz.com, November 5, available at: http://www.greenbiz.com/. Accessed 10 November 2013.

Davies, P., 2015. Reporting for Reporting's Sake? Sustainability Reporting in Australia. 20 May, Pro-bono Australia News., https://probonoaustralia.com.au/news/2015/05/ reporting-for-reportings-sake-sustainability-reporting-in-australia/. Accessed 13 September, 2016.

Dahlstrom, R, 2011. Green Marketing Management, Mason, OH, South-Western Cengage Learning.

Drucker, P.F., 1954. The practice of management. New York: Harper \& Brothers.

Epstein, M.J. Roy, M-J., 2001. Sustainability in action: Identifying and measuring the key performance drivers. Long Range Planning, 34, 585-604.

Fishman, C., 1988. Sustainable growth: Interface Inc., https://www.fastcompany.com/33906/sustainable-growth-interface-inc. Accessed 18 November, 2016.

Gallear, D. Ghobadian, A., Chen, W., 2012. Corporate responsibility, supply chain partnership and performance: An empirical examination. International Journal of Production Economics, 140, 83-91.

Gavronski, I. Klassen, R.D. Vachon, S. Machado do Nascimento, L.F. (2012). A learning and knowledge approach to sustainable operations. International Journal of Production Economics, 140, 183-192. 
Gössling, S., Hall, C.M., Peeters, P., Scott, D., 2010. The Future of Tourism: Can Tourism Growth and Climate Policy be Reconciled? A Mitigation Perspective, Tourism Recreation Research Vol. 35(2), 119-130.

Governance and Accountability Institute, Inc., 2016. FLASH REPORT: Eighty One Percent (81\%) of the S\&P 500 Index Companies Published Corporate Sustainability Reports in 2015, http://www.ga-institute.com/nc/issue-master-system/newsdetails/article/flash-report-eighty-one-percent-81-of-the-sp-500-index-companiespublished-corporate-sustainabi.html. Accessed 27 December, 2016.

Grönroos, C., 2006. On defining marketing: Finding a new roadmap for marketing, Marketing Theory, 6(4), 395-417.

Gundlach, G.T., Wilkie, W.L., 2009. The American Marketing Association's New Definition of Marketing: Perspective and Commentary on the 2007 Revision. Journal of Public Policy \& Marketing: Fall 2009, 28 (2), 259-264.

Hall, C.M., 1999. Rethinking collaboration and partnership: A public policy perspective. Journal of Sustainable Tourism, 7 (3\&4), 274-289.

Hopkins, M.S., 2011. What's your company's sustainability filter?, Sloan Management Review, January, 1-5.

Interface Inc., 2017. Interface, http://www.interfaceglobal.com/default.aspx/. Accessed: 27 March, 2017.

Jaworski, B.J., 2011. On managerial relevance. Journal of Marketing, 75 (July), 211-224.

Jones, P., Clarke-Hill, C., Comfort, D., Hillier, D., 2008. Marketing and sustainability. Marketing Intelligence and Planning, 26 (2), 123-130.

Katz, C., 2014. Inside San Francisco's quest to recycle all trash by 2020, greenbiz.com. Accessed 12 July, 2014.

Kennedy, S., Whiteman, G., van den Ende, J., 2016. Radical innovation for sustainability: The power of strategy and open innovation. Long Range Planning, doi: 10.1016/j.lrp.2016.05.004.

Kirchgeorg, M., Winn, M.I., 2006. Sustainability marketing for the poorest of the poor. Business Strategy and the Environment, 15, 171-184.

Kotler, P., Armstrong, G., 2013. Marketing, $9^{\text {th }}$ Edition, Pearson Australia.

Kotler, P., \& Keller, K.L., 2006. Marketing management (12th ed.). Upper Saddle River, NJ: Pearson Prentice Hall.

Kotler, P., Levy, S.J., 1969. Broadening the concept of marketing, Journal of Marketing, 33 (January): 10-15. 
Kumar, P., 2016. State of green marketing research over 25 years (1990-2014): Literature survey and classification. Marketing Intelligence and Planning, 34 (1), 137-158.

Laughland, P., Bansal, T., 2011. The Top Ten Reasons Why Businesses Aren’t More Sustainable, Ivey Business Journal, January/February, http://iveybusinessjournal.com/publication/the-top-ten-reasons-why-businesses-arentmore-sustainable/ Accessed 18 December, 2016.

Lazer, W., 1969. Marketing's changing social relationships, Journal of Marketing, 33 (January), 3-9.

Leinaweaver, J., 2015. Is corporate sustainability reporting a waste of time? The Guardian, https://www.theguardian.com/sustainable-business/2015/jan/06/corporatesustainability-reporting-waste-time. Accessed 14 September 2016.

Luchs, M.G., Walker Naylor, R., Irwin, J.R., Raghunathan, R., 2010. The Sustainability Liability: Potential Negative Effects of Ethicality on Product Preference. Journal of Marketing, 74 (September), 18-31.

Lusch, R.F., 2007. Marketing's Evolving Identity: Defining Our Future. Journal of Public Policy \& Marketing, 26 (2), 261-268.

MacInnis, D.J., 2011. A framework for conceptual contributions in marketing. Journal of Marketing, 75 (July), 136-154.

Martin, D., Schouten, J., 2012. Sustainable Marketing, Upper Saddle River, NJ: Prentice Hall.

Matthes, J., Wonneberger, A., 2014. The skeptical green consumer revisited: Testing the relationship between green consumerism and skepticism toward advertising. Journal of Advertising, 43 (2), 115-127.

Maxwell, D., van der Vorst, R., 2003. Developing sustainable products and services, Journal of Cleaner Production, 11, 883-895.

McCarthy, E.J., 1960. Basic Marketing, A Managerial Approach. Homewood, IL. Irwin.

McKinsey and Company, 2014. Sustainability's Strategic Worth, http://www.mckinsey.com/business-functions/sustainability-and-resourceproductivity/our-insights/sustainabilitys-strategic-worth-mckinsey-global-surveyresults. Accessed 12 April, 2017.

Meany, L., 2014. IKEA, Microsoft and Google power business with wind, published July 1, Greenbiz.com. Accessed 12 July, 2014.

Mendleson, N., Polonsky, M.J., 1995. Using strategic alliances to develop credible green marketing. Journal of Consumer Marketing, 12 (2), 4-18. 
Minton, E., Lee, C., Orth, U., Kim, C-H., Kahle, L., 2012. Sustainable marketing and social media. Journal of Advertising, A Cross-Country Analysis of Motives for Sustainable Behaviors, 41 (4), 69-84.

Ostrom, A.L., Parasuraman, A., Bowen, D.E., Patricio, L. Voss, C.A., 2015. Service Research Priorities in a Rapidly Changing Context. Journal of Service Research, 18 (2): $127-159$.

Polonsky, M.J., Carlson, L., Fry, M.L., 2003. The Harm Chain: A Stakeholder and Public Policy Development Perspective, Marketing Theory, 3 (3), 345-364.

Porter, M. Kramer, M., 2011. Creating shared value: How to reinvent capitalism and unleash a wave of innovation and growth. Harvard Business Review, January-February, 1-17.

Porter, M.E., Kramer, M.R., 2006. Strategy and society: The link between competitive advantage and corporate social responsibility, Harvard Business Review, December, $1-17$.

Prothero, A., Dobscha, S., Freund, J., Kilbourne, W.E., Luchs, M.G., Ozanne, L.K., Thфgersen, J., 2011. Sustainable consumption: Opportunities for consumer research and public policy, Journal of Public Policy and Marketing, 30 (1), 31-38.

Porter, M.E., Kramer, M.R., 2011. Shared value: How to reinvent capitalism and unleash a wave of innovation and growth, Harvard Business Review, January-February, 2-17.

Quariguasi Frota Neto, J., Bloemhof-Ruwaard, J.M., van Nunen, J.A.E.E., van Heck, E., 2008. Designing and evaluating sustainable logistics networks. International Journal of Production Economics, 111, 195-208.

Seligmann, P. 2014. Walmart: the corporate empire's big step for sustainability. The Guardian, 22 May 2014, available at: https://www.theguardian.com/sustainablebusiness/walmart-sustainability-corporate-environment-conservation-suppliers, accessed 15 April, 2017.

Sheth, J.N., Parvatiyar, A., 1995. Ecological imperatives and the role of marketing, in Environmental Marketing: Strategies, Practice, Theories and Research, Eds. Michael Jay Polonsky, Alma T. Mintu-Wimsatt, pp. 3-20,The Haworth Press, New York.

Székely, F., Knirsch, M., 2005. Responsible leadership and corporate social responsibility: Metrics for sustainable performance. European Management Journal, 23 (6), 628-647.

Tollin, K., Christensen, L.B. Wilke, R. (2015). Sustainability in business from a marketing perspective. Journal of Strategic Marketing, 23 (6), 471-496.

Tollin, K. Schmidt, M., 2012. Marketing logics, ambidexterity and influence. Journal of Strategic Marketing, 20 (6), 509-534. 
United Nations General Assembly, 2015. Resolution adopted by the General Assembly on 25 September 2015: 70/1. Transforming our world: the 2030 Agenda for Sustainable Development, http://www.un.org/ga/search/view_doc.asp?symbol=A/RES/70/ 1\&Lang=E. Accessed 22 December 2016.

United Nations Global Compact, 2016. The world's largest corporate sustainability initiative, https://www.unglobalcompact.org/what-is-gc. Accessed 21 December 2016.

United Nations Framework Convention on Climate Change, 2015. The Paris Agreement, http://unfccc.int/paris_agreement/items/9485.php Accessed 17 December, 2016.

United Nations Sustainable Development Goals, 2015, Seventeen goals to transform our world, http://www.un.org/sustainabledevelopment/sustainable-development-goals/. Accessed 16 April, 2017

Unruh, G., Kiron, D., Kruschwitz, N., Reeves, M., Rubel, H. Zum Felde, A.M., 2016. "Investing For a Sustainable Future," MIT Sloan Management Review, May, http://sloanreview.mit.edu/projects/investing-for-a-sustainable-future/. Accessed 20 December, 2016.

Warren, C., Becken, S., Coghlan, A., 2016. Using persuasive communication to co-create behavioural change - engaging with guests to save resources at tourist accommodation facilities. Journal of Sustainable Tourism, http://dx.doi.org/10.1080/ $\underline{09669582.2016 .1247849 .}$.

World Commission on Environment and Development (WCED), 1987. Our Common Future. Oxford. Oxford University Press.

Walmart Corporate, 2011. Walmart To Generate Solar Energy At More Than 75 Percent Of Its Stores In California", http://www.walmartstores.com/pressroom/news/10699.aspx. Accessed 3 March 2012.

Wymer, W., Polonsky, M.J., 2015. The limitations and potentialities of green marketing. Journal of Nonprofit and Public Sector Marketing, 27, 239-262.

Yin, R.K., 2014. Case Study Research: Design and Methods, Las Angeles, Sage. 


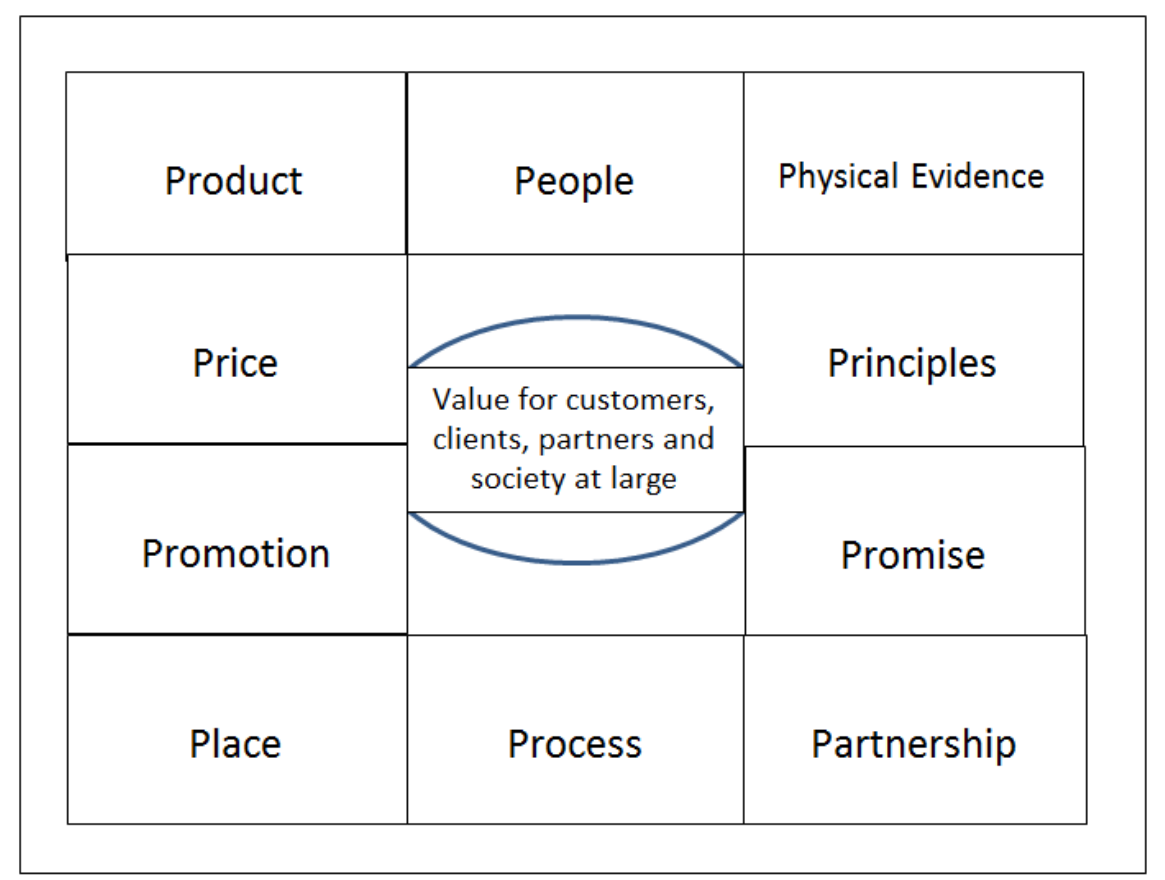

Figure 1: A Marketing Mix for Sustainability

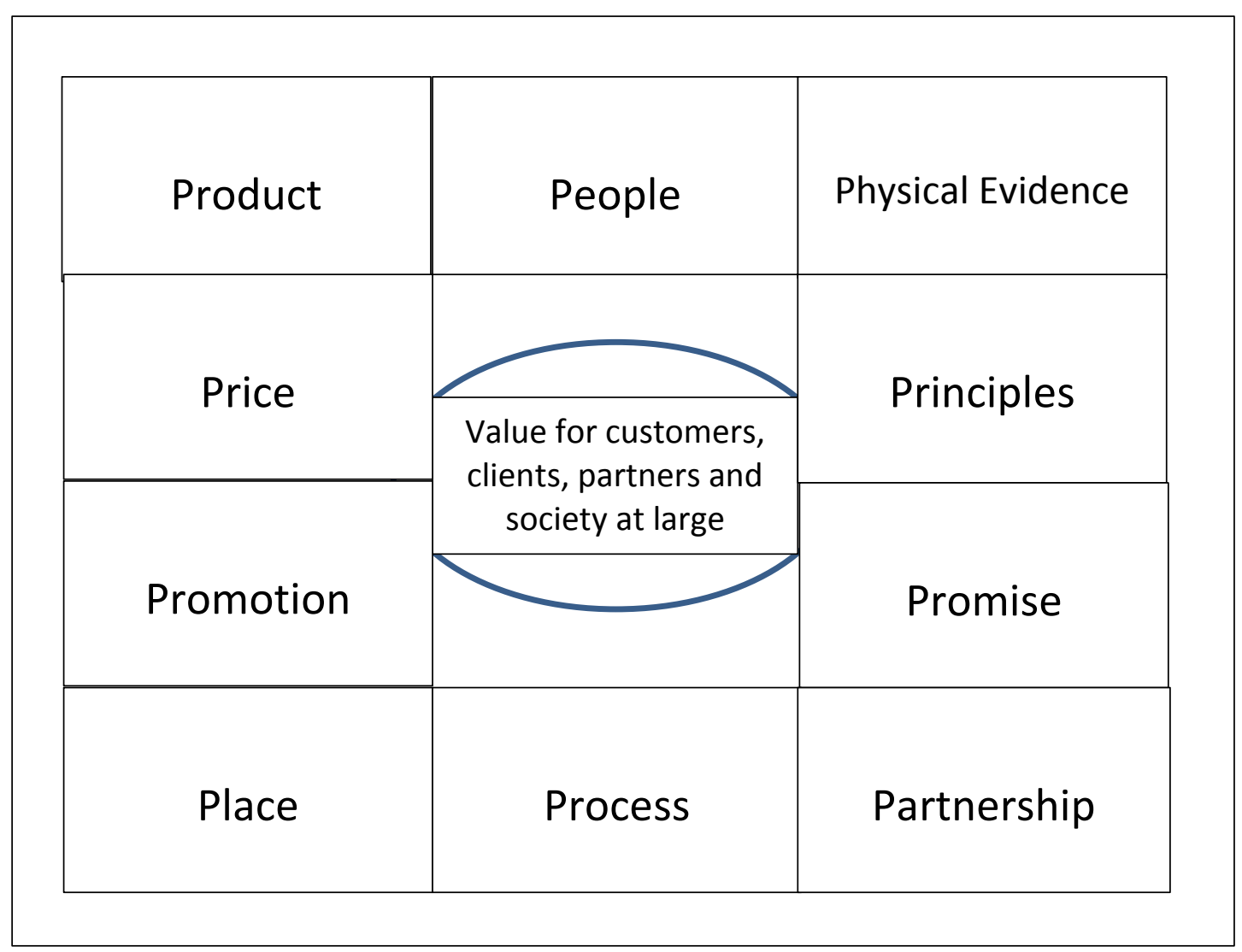

